\title{
Application of Process Mapping as an Improvement of an Integrated Management System in a Steel and Pipe Company in the Manaus Industrial Center
}

\author{
Lunna Maria Braga de Souza, Marcelo Albuquerque de Oliveira, Gabriela de Mattos Veroneze, \\ Dércio Luiz Reis, and Joaquim Maciel da Costa Craveiro
}

\section{ABSTRACT}

This academic work will demonstrate a project applied within a company of Steel, Tubes and Connections in the industrial pole of Manaus. The objective of this project is the unification, through an integrated communication system, of all sectors of the company. So that you no longer need to use other means of communication to connect the company and make it quick, automatic, and easy, in addition to being able to make decisions based on information in real time. For this purpose, process mapping was used, the improvement agent for the application of the study, these mappings were made using software called Bizagi.

Keywords: Integrated System, Modelling Software, Process Mapping.

\author{
Submitted : September 11, 2021 \\ Published : December 02, 2021 \\ ISSN: $2507-1076$ \\ DOI: $10.24018 /$ ejbmr.2021.6.6.1104 \\ Lunna Maria Braga de Souza* \\ Graduation student in Production Engineering, \\ Federal University of Amazonas, Brazil. \\ (e-mail: lunnambraga ${ }^{\circledR}$ hotmail.com) \\ Marcelo de Albuquerque de Oliveira \\ Professor, PhD, Master's Program in \\ Production Engineering, Federal University of \\ Amazonas, Brazil. \\ (e-mail: marcelooliveira ${ }^{@}$ ufam.edu.br) \\ Gabriela de Mattos Veroneze \\ Professor, PhD, Master's Program in \\ Production Engineering, Federal University of \\ Amazonas, Brazil. \\ (e-mail: gveroneze@ufam.edu.br) \\ Dércio Luiz Reis \\ Professor, PhD, Master's Program in \\ Production Engineering, Federal University of \\ Amazonas, Brazil. \\ (e-mail: dercioreis@ufam.edu.br) \\ Joaquim Maciel da Costa Craveiro \\ Professor, PhD, Master's Program in \\ Production Engineering, Federal University of \\ Amazonas, Brazil. \\ (e-mail: jmaciel@ufam.edu.br) \\ *Corresponding Author
}

\section{INTRODUCTION}

According Correa (1998), Enterprise Resource Planning has all sectors that assist to the company's routine, whether they are directly connected to the company strategy or auxiliary routines to the company's functioning.

Due to fast globalization on the last decades, most of the companies look for ways to remain competitive on market. To do this, it focused heavily on improving the performance of its internal processes, application improvements and automatization within others. From this scenario, it was born the application study about process mapping the operations stream in a company on Manaus Industrial Hub to the utilization of a software ERP. Mapped on processes, its operational particularities were identified, all sectors of the factory such as the inventory, sales, purchasing and financial sectors.

This work will be divided within the following topics: in the second topic the theoretical background will be presented; the third approaches the methodological procedures, where will be presented the used methodology to the project realization and the fourth will be the study case, which will be commented about the obtained results from the application of the methodology previously presented.

\section{LITERATURE REVIEW}

\section{A. Business Processes Management}

BPM stands for Business Process Management, and is a vision of an adaptable management way, developed with the aim to systematize and ease the complex individuals' organizational processes, in and out of the companies (Oliveira, 2014).

Brocke and Rosemann (2013) described that the main focus of BPM is guaranteeing that all the sectors are trained and aligned with each other and offer a process according to the aims and goals established by the company. Bălănescu et 
al., (2013) quote that the main companies use intern processes as advantages in the market, because of that they consider alignment of process mapping to compete in the market.

According to Pizetta (2020), the Management by processes will occur only if the company has its processes defined, standardized, and controlled, aiming to enhance the operational efficiency. Managing something unknown and without control is not something easy, almost impossible, therefore, the Processes Mapping meets the needs of Management. The author affirms that business process management is connected to strategies and goals of short, medium, and long-term defined by the company. These goals can be goals by sectors, departments, or individuals, but it must establish the best solutions to the problems found and that it has the best operation conditions, reducing costs and decreasing risks, increasing competitiveness.

Although, nothing of it is possible without total business comprehension, due to this process mapping meets this need, providing securely all the data to a good management. According to Pizetta (2020), Management processes is able to obtain: Operational and administrative control improvements; Financial control improvements; Efficient tools to results measurement; Mitigation of Financial and Operational risks; Costs reduction; Extra hours reduction; Achievement goals efficiency; Serve customer prospects.

\section{B. Process Mapping}

The process mapping is a method to know the company routine, creating a map of Administrative and Operational processes, aiming to optimize its operation, and it is called Business Process Management. All the collaborators' functions, in other words, the daily routines activities, are configured as processes. When we map a company's process, we actually understand how this company works, which are its particularities, its features, its resources, its methods and its deliveries, in this regard, the effectiveness of results is directly connected to the means that perform the actions

According to Pizetta (2020), below are some of the purposes of process mapping:

- Help clarifying hierarchy: The process mapping establishes a hierarchy because it allows us to portray how a company's productive process is, aiming to follow the work stream, from the production of the company, to decision makers and in fact who carries out the task. With the sectors divided, the chances of having intern promotion are greater. Having the sector mapping makes it easier also to recognize who communicates with who. It is also a technique to evaluate a company's development and each department, in a clearer way.

- Keep goals aligned: All companies have an objective or a goal of objectives. With the sector mapping, it is easier to provide interaction and guarantee that each sector is doing the right part to the bigger objective. Mapping is a way to establish a certain context, to each sector, and all the others, showing the weight of the activity to the whole. This is extremely important to make sectors similar, such as marketing and sales, if they keep themselves close, interact and share the objectives. The mapping is essential to new collaborators. By knowing to whom he is going to work closer, the connection between sectors can be quicker and more efficient. To the managers, it is fundamental to know what happens in the organization. Although, with an increasingly complex mesh, mapping becomes essential to ensure goal alignment, the interaction between sectors and the notion that each one of them is doing their part.

- Helps to make security easier: Another point of view of sector mapping is to make a company's security easier. Each sector and each employee present a vulnerability that can be explored, and there must be established security measures to each one of them. Although, to be able to impose these measures, it is necessary to know the risks, identifying all the sectors, which is its scope actuation and the risks which it might be exposed to and ends up exposing the company. Knowing exactly the structure of a company's sector, the leaders can draw up a security plan from the risks management that each of them present, to guarantee that the company is always well protected.

- Identifies bottlenecks: The process mapping helps to identify the operational bottlenecks that show up in the progress that can prejudice the company progress. With this, it is possible that there are delays on final product delivery, which makes the customers unsatisfied with the company and to the collaborators it is harder to achieve goals.

- Quality improvement: When the customer hires the product and/ or service, he always looks for quality, efficiency, and standardization. Because of that, the process mapping is an important ally for that, because it optimizes the steps and shapes the customers' expectations. Furthermore, process mapping does not help the company to depend only on people, but on the operational processes as a whole.

\section{Enterprise Resource Planning}

The ERP, "Enterprise Resource Planning”, is an integrated system to management more used by the companies. It integrates and aggregates many functionalities of productive and business processes, supporting many activities such as Sales, Purchases, warehouse, Logistics and other sectors. Because it is an integrated database system, it allows the use of the information generated by another module and assists data and information stream between sectors of the company, avoiding data repetition.

Having an ERP system makes your data centralized in only one environment, making your information fast and efficient, allowing each module or sector, to use real information and not by estimative, and obtain the generation of reports of each sector individually or of many sectors collectively are generated in an only way, depending just on one software.

Deloitte (1998) explains that ERP is a software that integrates all business processes, where everyone in the company can share common practice and data in a real-time environment. According to Ramesh and Ravi (2017), ERP is an information system integrated that assists all departments of a company. The system has been more used in industries because the ERP modules are able to interact with other systems of the organization, even with a variable degree of difficulty and, depending on the supplier, the ERP can be changed through programming. 


\section{METHODOLOGY}

The project to implement an ERP system is initially drawn up with the aim to reduce costs and improve the collaborators capability, besides streamlining decision-making and operational processes of all collaborators. A study was carried out with a developer company from São Paulo.

For results to be achieved, all the projects must be structured, well organized, and planned and involving all the sectors and/or departments that will receive the software SAP Business One (SAP, 2020). The current work follows the following steps to the reality of the studied company, according to Fig. 1.
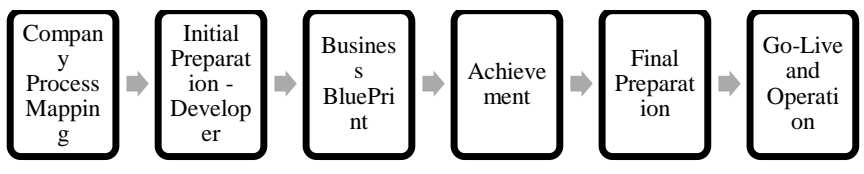

Fig. 1. Steps of the Implementation of ERP System.

\section{A. ERP System Implementation}

The ERP system implementation is considered one of the most complex to the organization, because it is about the organizational changes process, which affects directly on the management model, on organizational architecture, on business management processes and especially of people Caldas and Wood Júnior, 1999). Different authors also support the importance of ERP system (Demirkesen and Ozorhon, 2017; Lockamy III and McCormanck, 2004; Mendonça Júnior et al., 2018; Mittal et al., 2018; Rybski and Jochem, 2016).

\section{1) Initial preparation}

Knowing the company evaluating with transparency all the process mapping and existing practices, as well as old software and its performance. This is necessary due to the fact of identifying which information the company needs and, which will be available to the users. Right after, it has elaborated a process resizing, eliminating duplicate functions, as well as systems that cannot assist to the company's expectation. In the initial preparation, it has also made the company server installation.

\section{2) Business BluePrint}

The second phase of the project is made the detailed descriptions of processes that come from the process mapping previously done and the requirements that the company needs. It is an essential document for implementation, in this document is shown all the important configurations to adequate the processes in ERP. Besides that, data survey workshops and process designs are held.

\section{3) Realization}

The third phase of the project is destined to the database construction. In other words, an importation of loads from the old system is done to the new one, and a data parameterization is done. With the import data, a validation is done where is evaluated if those data were imported correctly, and single tests are also carried out that analyze artificially the software to guarantee that each part works as it must and with it, the customizations and/or development to enhance the collaborators' processes.
After that, homologation tests, in other words, it is a test between the key user of each sector and the developer company, to guarantee once more that the program assists to the specificities and assists perfectly what is desired.

\section{4) Final preparation}

The fourth phase consists of training to the collaborators and an integrated test because once it is a different technological innovation in the company. The new system will bring a brand-new impact to all the employees. In addition, there is the need for specific training with each sector, so they can benefit the most from this innovation, get used to the new process and prevent problems from occurring.

\section{5) Go-Live and Operations}

In the fifth phase, the system starts getting into production, in technical words, in GO-live. It is also carried out the pending issues' conclusion, such as stock balance, clients and suppliers, giving them continuous support (helpdesk).

\section{B. Sector's Mapping}

The process mapping is a method to get to know the routine of a company, creating an administrative and operational process map, aiming to optimize its operation. All the collaborators' functions, in other words, the daily routine activities are characterized as the processes. The most used tool to do process mapping was carried out in a software called Bizagi (Bizagi, 2020), an easy understanding system to all kinds of people, because it allows to draw, document, diagram and publish the processes simply, in a transparent way and graphically organized.

\section{1) Process Mapping Tool}

In this step, is made a survey of all sectors of the company, it's made an appointment with each key user, responsible people of the sector, to make a recorded interview of how is the collaborator's routine. Once this is done, it is transferred to the software Bizagi to transcribe what was informed, along with the decision-making process. Szilagy (2010) presents the main elements of each process mapping carried out in Bizagi: i) Flow objects; ii) Connecting objects; iii) Swimlanes; and iv) Artifacts.

The flow objects reproduce the elements related to processing actions (Table I). Connecting objects link the flow objects indicating its sequence (Table II). The swimlanes allow the processes to be separated by different agents responsible for the execution (Table III). The artifacts represent the flow complementary information (Table IV). Below follows the boards that (Szilagy, 2010).

\section{2) Process mapping of the studied company}

The studied company is from the steel, tubes, and connection's field it supplies products to the national market. Nowadays, it is divided within the sectors, such as Administrative (Financial, Purchases, Tax, Enhancement Projects, Human Resources), Commercial (Sales and Projects), Operational (PCP, Production, Warehouse and Logistics). The proposal of this work had as aim to map all the sectors of the company that use the system and migrate to one software system more agile and automatic as a factor agent to the company's enhancement. It has a focus to unify all the sectors, so it will not be necessary to use other means 
of communication anymore to interconnect the company and streamline its intern process.

This section presents the process flows surveyed during the software ERP installation. To map the sectors, were made appointments with key users on alternate days.

TABLE I: GRAPHIC ELEMENTS BPM - FLOW SOURCE OBJECTS

\begin{tabular}{c|l|c}
\hline \hline \multicolumn{1}{c}{ TABLent } & \multicolumn{1}{c}{ Description } \\
\hline \multirow{2}{*}{ Event } & $\begin{array}{l}\text { An event that happens during the execution of } \\
\text { the process, and is divided into three stages: } \\
\text { Start, Intermediate and End. }\end{array}$ \\
\hline Activity & $\begin{array}{l}\text { It is a task that is included within a process. It is } \\
\text { used when work in the process is not } \\
\text { subdivided. }\end{array}$ \\
\hline Gateway & $\begin{array}{l}\text { They are places within a business process } \\
\text { where the flow can take two or more different } \\
\text { paths. }\end{array}$ \\
\hline $\begin{array}{l}\text { Sub- } \\
\text { process }\end{array}$ & $\begin{array}{l}\text { It is an activity that depends on the parent } \\
\text { process and has visibility of data from the } \\
\text { parent process. No data mapping required. }\end{array}$ \\
\hline \hline
\end{tabular}

TABLE II: GRAPHIC ELEMENTS BPM - CONNECTING OBJECTS

\begin{tabular}{l|l|c}
\hline \multicolumn{1}{c|}{ Element } & \multicolumn{1}{c}{ Description } & Symbols \\
\hline \multirow{3}{*}{$\begin{array}{l}\text { Fequence } \\
\text { Flow }\end{array}$} & $\begin{array}{l}\text { It is used to indicate the order in which } \\
\text { activities will be performed in a process. } \\
\text { Each flow has only one source and one } \\
\text { destination. }\end{array}$ \\
\hline \multirow{3}{*}{ Flow } & $\begin{array}{l}\text { It is used to show the exchange of } \\
\text { messages between two process } \\
\text { participants. In BPMN, two separate }\end{array}$ \\
$\begin{array}{l}\text { Pools in the diagram represent two } \\
\text { participants (a business entity or a process } \\
\text { role, for example). }\end{array}$ & $\begin{array}{l}\text { Used to associate information with stream } \\
\text { objects. Graphic or textual objects that are } \\
\text { not stream objects can be associated with } \\
\text { stream objects. }\end{array}$ \\
\hline \hline
\end{tabular}

TABLE III: GRAPHIC ELEMENTS BPM - SWINLANES

\begin{tabular}{c|c|c}
\hline \multicolumn{1}{c|}{ TABLent } & \multicolumn{1}{|c}{ Description } & Symbols \\
\hline Pool & Represents a participant in the process. & \\
\hline Lane & $\begin{array}{l}\text { Lanes create sub partitions of a Pool. } \\
\text { Lanes are used to organize and categorize } \\
\text { the elements of the process. }\end{array}$ & \\
\hline \hline
\end{tabular}

\begin{tabular}{l|l|l|}
\hline \multicolumn{3}{c}{ TABLE IV: GRAPHIC ELEMENTS BPM - ARTIFACTS } \\
\hline \hline \multirow{2}{*}{ Element } & \multicolumn{1}{c}{ Description } & \multicolumn{1}{c}{ Symbols } \\
\hline Troup & $\begin{array}{l}\text { It is a Artifact that provides a visual } \\
\text { mechanism for group elements of a } \\
\text { diagram informally. }\end{array}$ \\
\hline Annotation & $\begin{array}{l}\text { They are mechanisms used by modelers to } \\
\text { provide additional information to diagram } \\
\text { readers of business process. }\end{array}$ \\
\hline $\begin{array}{l}\text { Data } \\
\text { Object }\end{array}$ & $\begin{array}{l}\text { Provide information about as documents, } \\
\text { data and other objects are used and updated } \\
\text { during the process. considered artifacts } \\
\text { because they don't have direct effect on the } \\
\text { flow of sequence or flow of process } \\
\text { messages, but they provide information } \\
\text { about what activities need to be performed } \\
\text { and what they produce. }\end{array}$ \\
\hline $\begin{array}{l}\text { Data } \\
\text { storage }\end{array}$ & $\begin{array}{l}\text { Offers activities a mechanism to rescue or } \\
\text { update the information stored that will } \\
\text { persist beyond the scope of the process. }\end{array}$ \\
\hline \hline
\end{tabular}

\section{1) Purchase Sector}

The purchase sector exhibited in the Fig. 2 presents the company process mapping. The identification of the need of stock purchase and the use consumption is made by the executive director of the company, who identifies the products and requests from the purchase sector to generate the purchase listing. To the input need for the production, the request comes from the PCP. After that, the purchase sector makes the quotation of the selected products with the suppliers, defines, which is the best budget and releases the products and the suppliers on the system, then requesting the purchase, after it is done a contact with the supplier asking if he has a carrier, in case the answer is yes, finishes the request, in case the answer is no, ask to deliver in the affiliated carrier to the company. With this, is generated the documents in Bills to Pay, according to the payment condition (Fig. 2).

\section{2) Sales Sector}

The sales sector has two types of sales. Type 1 are products from the commerce, are resale commodities that don't suffer modifications and type 2 are products from the industry, products manufactured to an intermediary good or a final good, depending on the utilization and the customer type, whether it's a final consumer or a contributing consumer (Fig. 3 ). Its process starts when the client comes to the stores or the salesperson prospecting to the client about other means of communication, the steps in the system start with the budget, and can be industry products (products of final good or intermediary good) or commerce (resale), and with the budget approval, it is transformed to sales request. The sold products by the commerce are forwarded directly to the warehouse and the supply separation and written off, while the products sold by the industry are forwarded to the PCP through email and skype, to carry out service orders that were demanded. In the process ending, the customer is directed to the cashier, if the form of payment is in cash, cards and/or cash deposit, or the billing sector, that is sales with payment form in bank ticket.

\section{3) Production Control Planning Sector}

The flow in the production control planning sector comes from the demand of the sales sector or also from the general executive director's request to store the stock products (Fig. 4).

Fig. 4 shows the flow which came from the client's demand, the salesperson forwards by email the sale request by the client to the PCP. With this, the PCP makes the production demand from that budget. Before that, it is carried out an analysis of the service orders demanded to determine a delivery date of these products. This way, it's created in the system an opening of service with the quantity of items produced and the composition of products to the formation of the final or intermediary product, after it's verified which production sector will be forwarded and if the product has a technical draw, if there has, it must go to the drawing sector to take to the production, after the production notifies that it has been manufactured, verify if the demand is according to what has been requested, register a new product in the system, then, the salesperson makes contact with the customer 


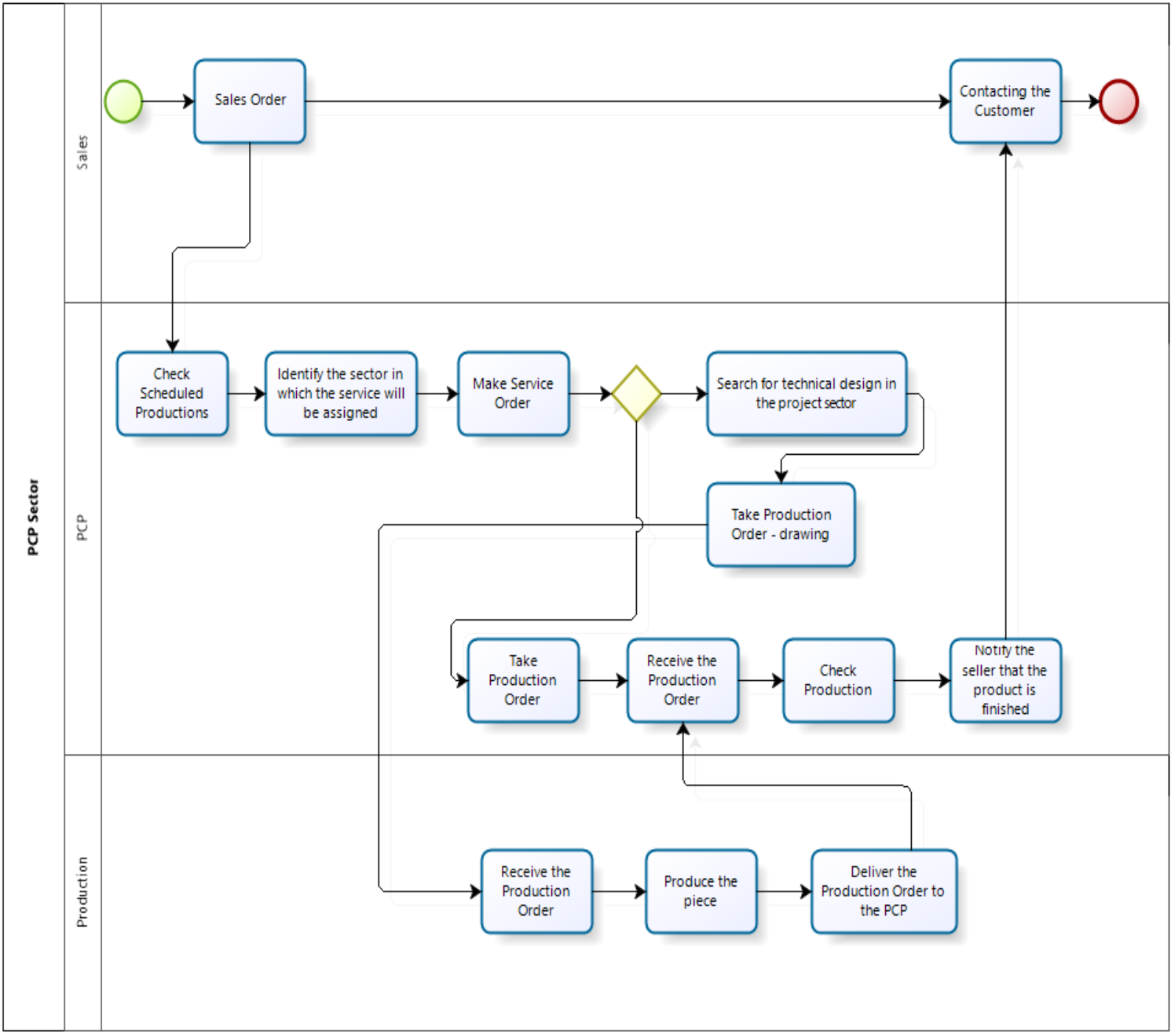

Fig. 2. Purchase Sector.

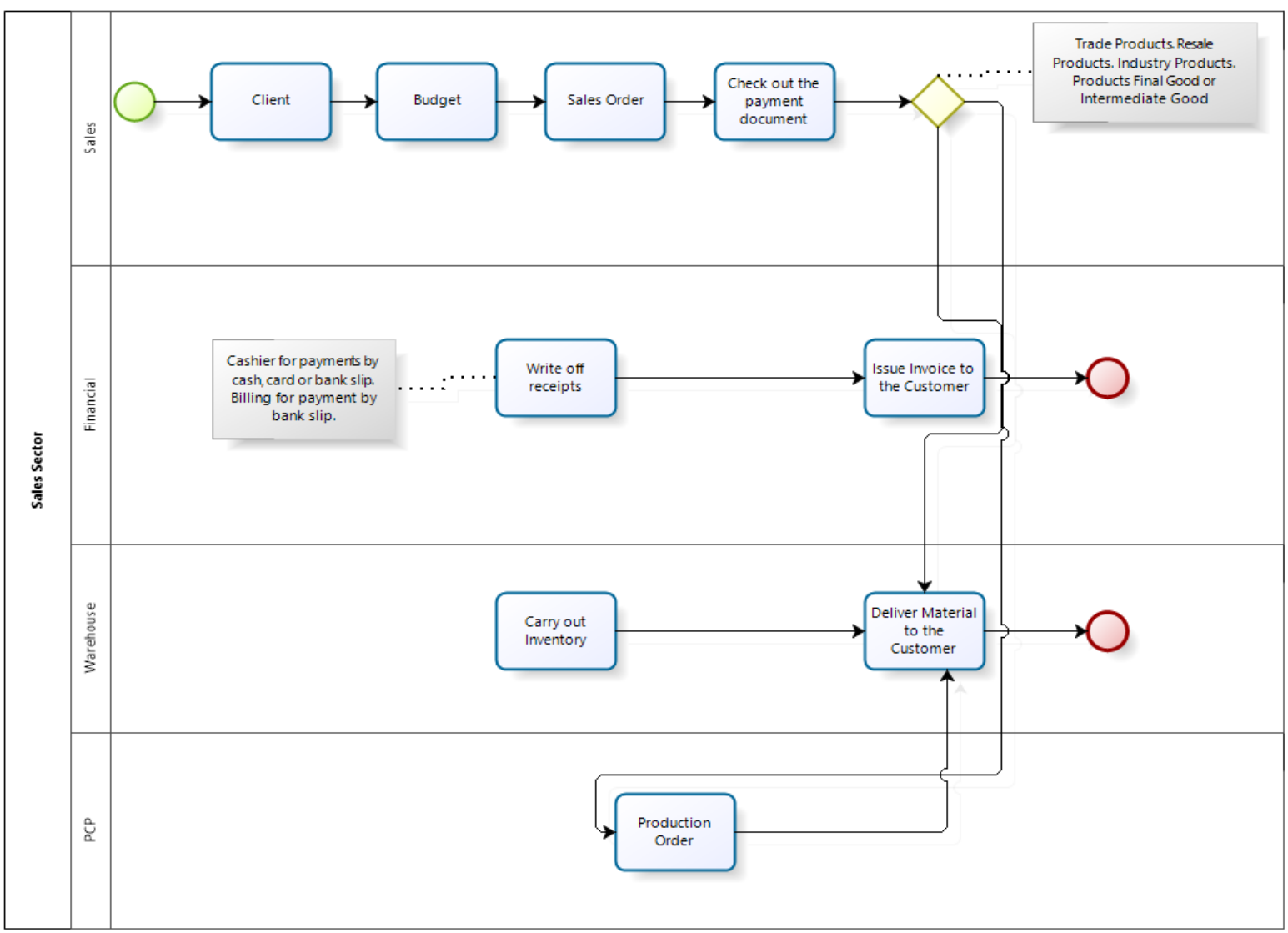

Fig. 3. Sales Sector. 


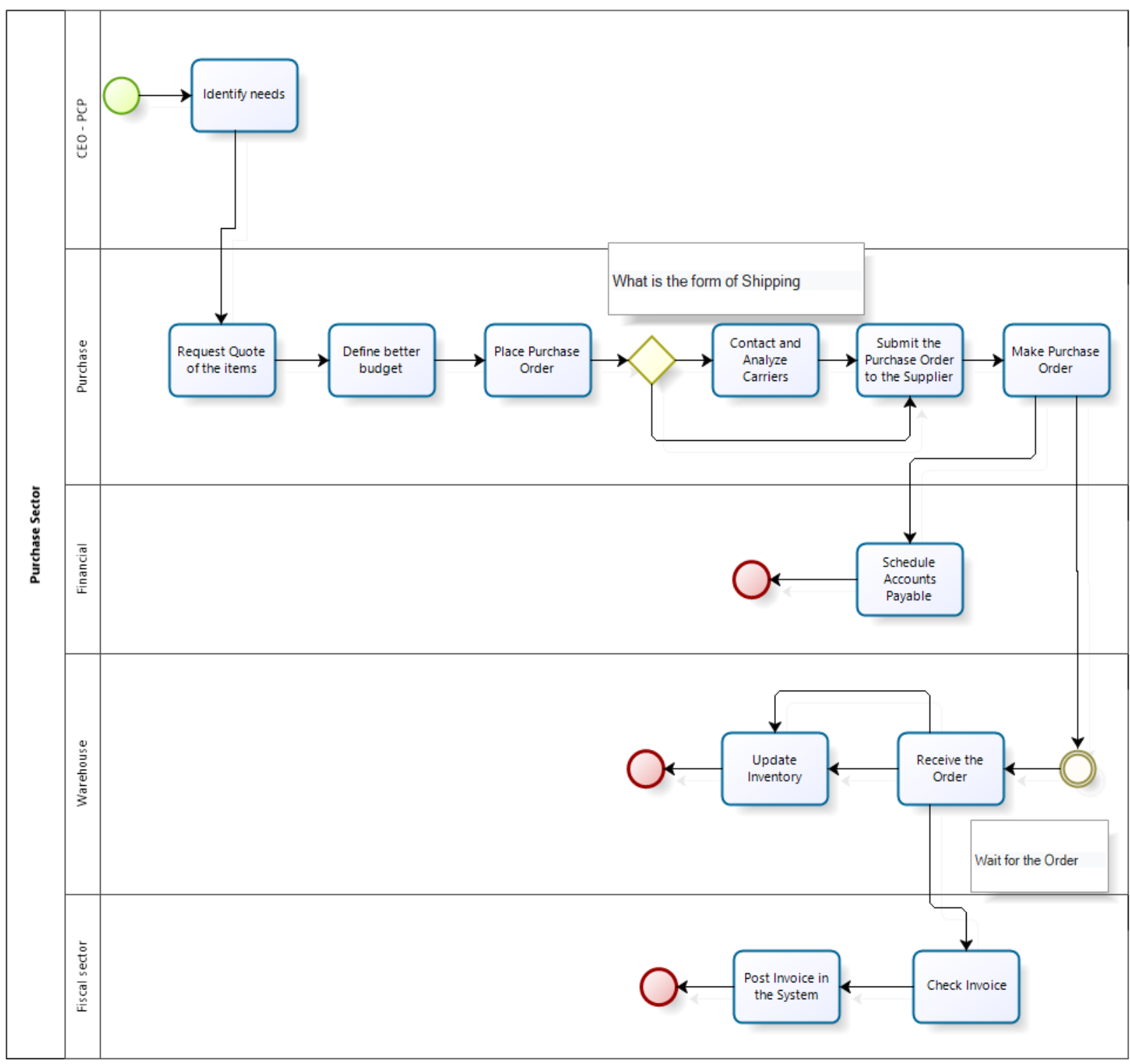

Fig. 4. Production Sector.

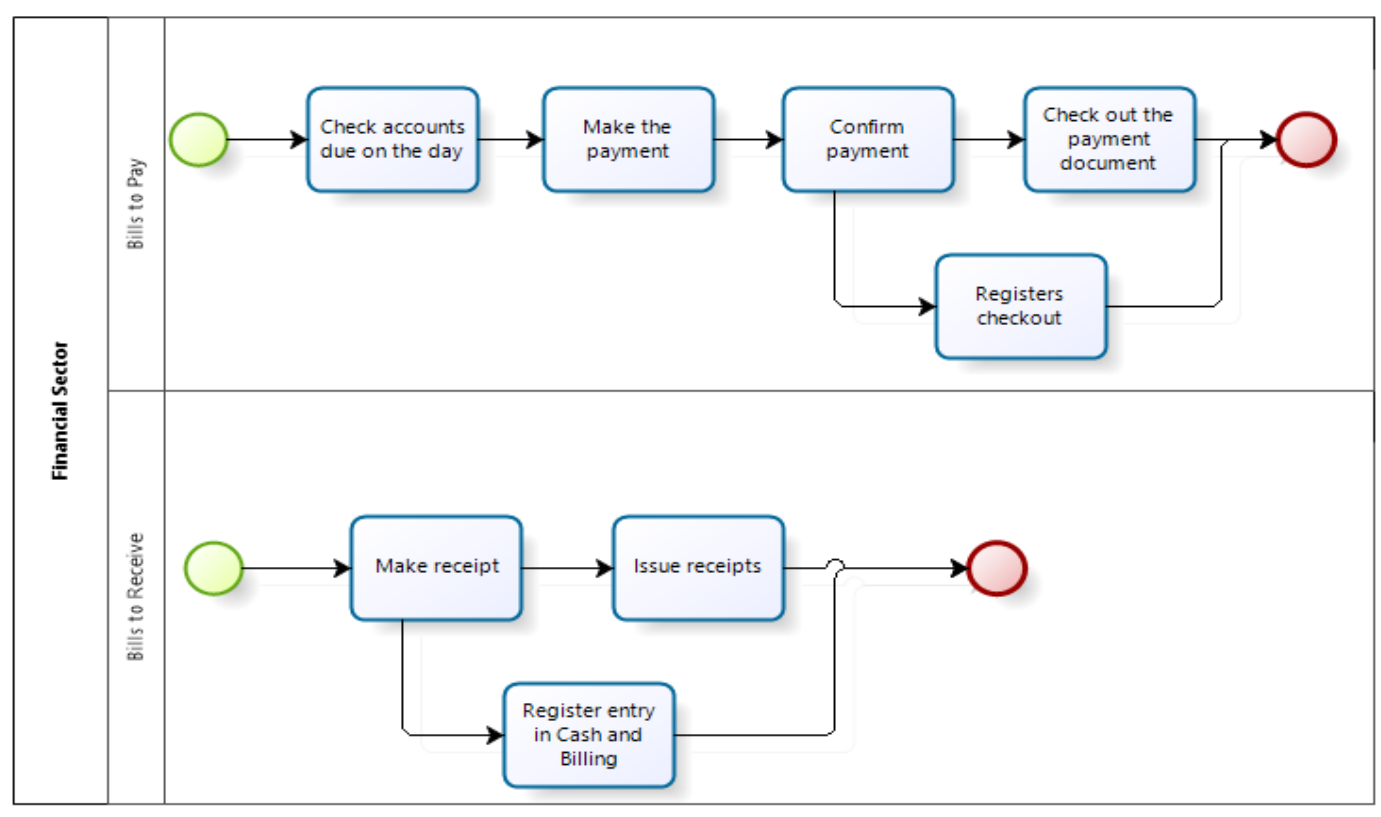

Fig. 5. Financial Sector. 


\section{4) Financial Sector}

The financial process mapping is shown in the Fig. 5. The sector was divided into two sub sectors: Bills to Receive and Bills to Pay. One is responsible for the output of values cash amounts and the other at the entrance of the company.
In the accounts payable sector, queries are made daily, the documents due are separated by the dates. In this sector, the payment of documents is made, and, after confirmation, they are written off in the system. It is the accounts payable sector that has the decisive power for decision making, as they need analyze whether that "investment" aggregates within the company.

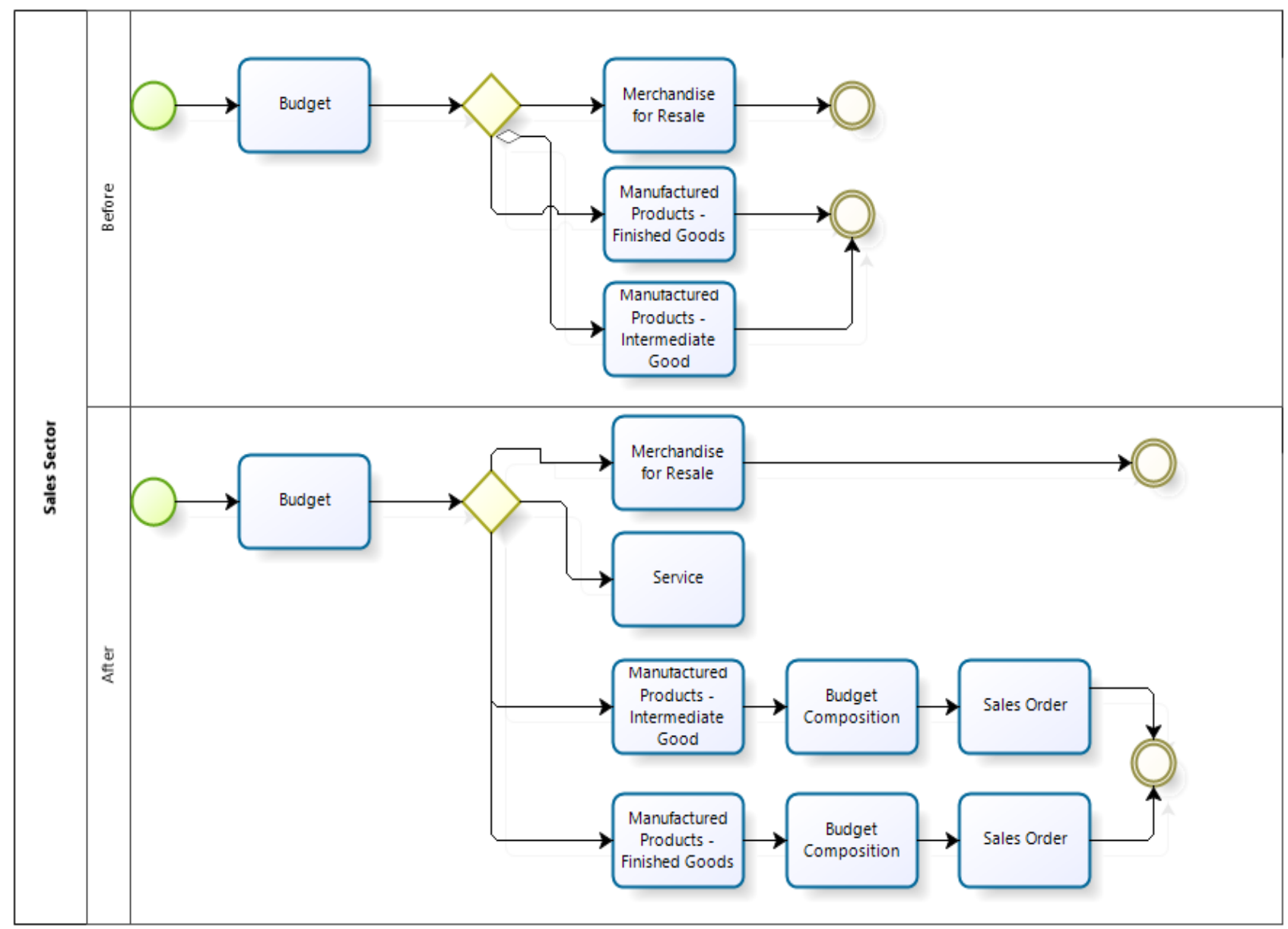

Fig. 6. Sales Sector Optimized.

\section{RESULTS AND DISCUSSIONS}

With the study of process mapping in the company, it was seen that the interconnection of information from the commercial, administrative and production sectors was done by 3 means of communication, namely, current software, email and skype. Therefore, some data was lost within the system.

After the implementation of the new system, the project brought a significant improvement in this part of communication, as the system has relationship maps, which are links to documents that show where all that information passed until reaching its destination.

Another significant improvement in the project took place in the sales and production sector. Previously there were only two types of sales, namely, trade and production. With the new system, a new business opportunity opened up, with the opening of a new service production line. That is, services that the customer brings the raw material, or the company provides the product and service. Fig. 6 shows the new mapping of the sales process within the new system.

Another important result with the implementation of the project was the communication between the sales, projects (design) and production sectors.

In the old system, it was not possible to identify when a sales order was for industry or commerce, for example. Thus, in order to have differentiation, the salesperson had to send an e-mail with the budget to the Production Control Plan sector with the details that the customer wanted.

From the new ERP software, when the seller signals in the budget that a product has a budget composition, that is, it needs to be manufactured according to such criteria, the PCP automatically receives an alert within the system to open this type of production order. If the sales order has a technical drawing, the drawing department can access the budget and attach the project, without the need for interference from another system. In addition, when the product is finished and registered in the system by the $\mathrm{PCP}$, it can notify the seller through the system's internal chat that the product has been finished. In this way, the seller will contact the customer to 
communicate about the availability and removal of the material.

After the implementation of the new system, the project has brought a significant enhancement in this communication part, because the system has maps of relations, which are attachments to documents that show from where came all that information to arrive in the destiny, besides the decentralization of decision-making of the executive directors of the company. It also brought the possibility to withdrawing reports by modules and managers and directors can have a total productive control of all collaborators.

The implementation project had difficulties in the part of user's adaptation with the software, because it directly affects the productive process of all, with this some showed certain resistance to learn about the new software, because it's a new system, with different methodologies, decentralized and organized, and it made the project estimated implementation time to be more extended so the collaborator could have more adaptation with the new.

\section{CONCLUSIONS}

This work presented the flow processes mapping of a company from the field of steel, tubes and connections that supplies products to the national market. As a technique of request extraction, interviews were made with the key-user of the company processes, with a questionnaire and screen records, applied during those interviews.

For contractual reasons of confidentiality, neither the answers nor the videos can be attached to this work. The process mapping studied were a) sales, responsible for the management of requests and acquisition of products and supplies for the company, and the stock control; b) financial responsible for the management of the values transition of the company; c) sales, which make direct contact with the customers and make sales; and d) production control planning, which manages the support to the production.

With the benefits of process mapping, the companies can streamline their processes in the ERP system, decreasing the request hours used to be done previously, interconnected the communication within only one system, without needing a third communication mean and can increase also the types of sales services in its process, opening more two production lines in the company.

\section{ACKNOWLEDGMENT}

The authors thank the Production Engineering Department (DEP) of the Federal University of Amazonas (UFAM) for their support and structure.

Special acknowledgement to the institutions and people involved to the final consolidation of this work that has been authorized through the agreement 001/2020 from the Cooperação Técnico-Científica celebrated between Fundação Universidade do Amazonas (FUA), Fundação de Apoio ao Ensino, Pesquisa, Extensão e Interiorização do IFAM (FAEPI) and the company Samsung Eletrônica da Amazônia LTDA (SEDA-M), within the project's scope of capacitation and research, which has been done by the academic unity FTUFAM.

\section{REFERENCES}

Bălănescu, V., Soare S, P., Beliciu, V., and Alpopi, C. (2013) The Impact of Business Process Management on Organizational Strategy. Business Excellence and Management, 3(2), 21-28.

Bizagi. (2020) http://www.bizagi.com/pt/produtos/bpm-suite/modeler.

Brocke, J. V.; Rosemann, M. (2013) Manual de BPM: Gestão de processos de negócio. Porto Alegre: Bookman.

Caldas, M. P., Wood Júnior, T. (1999) How Consultants Can Help Organizations Survive the ERP Frenzy. Meeting Annual Academy of Management, Chicago.

Corrêa, H. L. (1998). ERPs: por que as implantações são tão caras e raramente dão certo?. Simpósio de Administração da Produção, Logística e Operações Industriais. Anais. São Paulo: FGV-SP, p. 288 300 .

Deloitte Consulting. (1998) ERP's second Wave. TECHWEB. www.techweb.com.

Demirkesen, S., and Ozorhon, B. (2017) Impact of integration management on construction project management performance. International Journal of Project Management., vol. 35, no. 8, pp. 1639-1654.

Lockamy III, A.; and McCormanck, K. (2004) The development of a supply chain management process maturity model using the concepts of business process orientation. Supply Chain Management: An International Journal., 9(4), 272-278.

Mendonça Júnior, F., Oliveira, M. A., Montenegro, M.; Ramesh, T., Pedroso, G. A. C. (2018) Industry 4.0 as a way to enhance Lean Manufacturing and Six Sigma. Fifth European Lean Educator Conference, pp. 152160.

Mittal, S., Khan, M. A., Romero, D., and Wuest, T. (2018) A critical review of smart manufacturing \& Industry 4.0 maturity models: Implications for small and medium-sized enterprises (SMEs). Journal of Manufacturing Systems, vol. 49, no. November, pp. 194-214.

Oliveira, W. (2014) O que significa BPM - Benefícios, aplicações e estudos. https://www.venki.com.br/blog/o-que-e-bpm/.

Pizetta, M. (2020) Mapeamento de Processo (BPM) - Do Zero ao As Is. https://www.udemy.com/course/mapeamento-de-processos-bpm-dozero-ao-asis/.

Ramesh, N., and Ravi, A. (2017) Enhancing the performance of micro, small and medium sized cluster organization through lean implementation. International Journal of Productivity and Quality Management, vol. 21 , no. 3 , pp. 325-342.

Rybski, C., and Jochem, R. (2016) Benefits of a Learning Factory in the Context of Lean Management for the Pharmaceutical Industry. Procedia CIRP, vol. 54, pp. 31-34.

SAP. (2020) http://go.sap.com/corporate/en/company.

Szilagy, D. C. (2010) Modelagem de Processos de Negócio - um Comparativo entre BPMN e UML. Programa de Mestrado em Tecnologias da Inteligência e Design Digital - Pontifícia Universidade Católica de São Paulo. São Paulo.

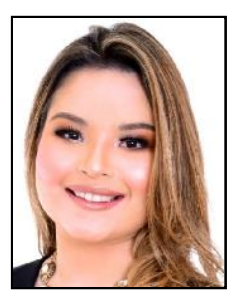

Lunna Souza is a student of Production Engineering at the Federal University of Amazonas, and researcher under SUPER project.

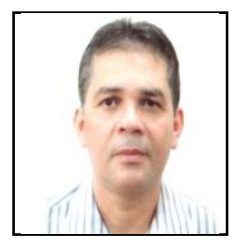

Marcelo Oliveira is an Adjunct Professor of Department of Production Engineering and member of Master Program in Production Engineering, Federal University of Amazonas. He has published several Research Papers related to Engineering area.

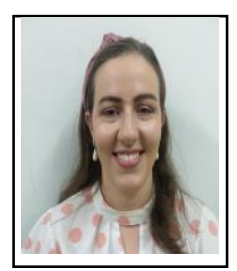

Gabriela Veroneze is an Adjunct Professor, Department of Production Engineering and member of Master Program in Production Engineering, Federal University of Amazonas. She has published several Research Papers related to Engineering area. 
European Journal of Business and Management Research www.ejbmr.orga

Dércio Reis is an Adjunct Professor, Department of Production Engineering and member of Master Program in Production Engineering, Federa University of Amazonas. He has published several Research Papers related to Engineering area.

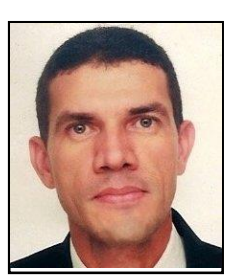

Joaquim Craveiro is an Adjunct Professor, Department of Production Engineering and member of Master Program in Production Engineering, Federal University of Amazonas. He has published several Research Papers related to Engineering area. 